\title{
Roe Deer Census by Pellet-group Counts ${ }^{1}$
}

\author{
Ryszard DZIĘCIOŁOWSKI
}

\begin{abstract}
Dzięciołowski R., 1976: Roe deer census by pellet-group counts. Acta theriol., 21, 26: $351-358$ [With 3 Tables \& 1 Fig.].

Pellet-group counts were taken in a big pen (ca 87 thous. $\mathrm{m}^{2}$ ) to determine whether they could be used to census roe deer, Capreolus capreolus (L in na e u s, 1758). Twenty counts made from August 1972 to May 1974 showed that the method was unreliable for estimating roe deer numbers in an unrestrained environment. An adaptation of pelletgroup counts to roe deer would require a determination of daily defecation rates during individual seasons of the year, assessment of the weathering rate and decomposition of pellets under various habitat conditions, and repeated field tests based on a known number of animals. Pellet-group counts may provide an index of use among various types of habitats by roe deer. A young plantation, a pole-sized stand of pine, and the ecotone between various habitat types were more intensively frequented by roe deer than a timber stand and thicket.

[Forestry Res. Inst., 02-362 Warszawa, Wery Kostrzewy 3, Poland]
\end{abstract}

\section{INTRODUCTION}

The technique of estimating deer population numbers by pellet-group counts was developed in North America in 1940 (B en et t et al. 1970). and later used for research and management purposes in northern USA and southern Canada ( $\mathrm{J}$ u lande $\mathrm{r}$ et al. 1963). Its main applications were to index trends in herd numbers ( $\mathrm{R}$ o b in e t t e et al. 1958) and to appraise habitat use by game animals and cattle ( $\mathrm{R} \circ \mathrm{g}$ er s, et al. 1958).

There have been several attempts to use the pellet-group technique in Europe, namely in USSR (Y u r g ens o n, 1970; P a d a ig a, 1970), France (D a buron, 1970), Scotland (W elch, 1971) and Poland (Dzięciolowski, 1974). The Padaiga's (1970) test was the only one concerned with roe deer.

In the pellet-group method it is assumed that animals defecate at a rather constant rate, that pellets are maintained sufficiently long to be found and counted, and that their age and time of deposition can be determined (R y e l, 1972).

1 The research was supported by the grant No. FG-PO-268, Forest Service, U.S.D.A.

[351] 
The purpase of the present work was to test whether pellet-group counts could be used to census roe deer, Capreolus capreolus ( $\mathrm{L}$ in$\mathrm{n}$ a e u s, 1758) and to determine the extent of deer use in various habitats. The need for a reliable census method is especially important

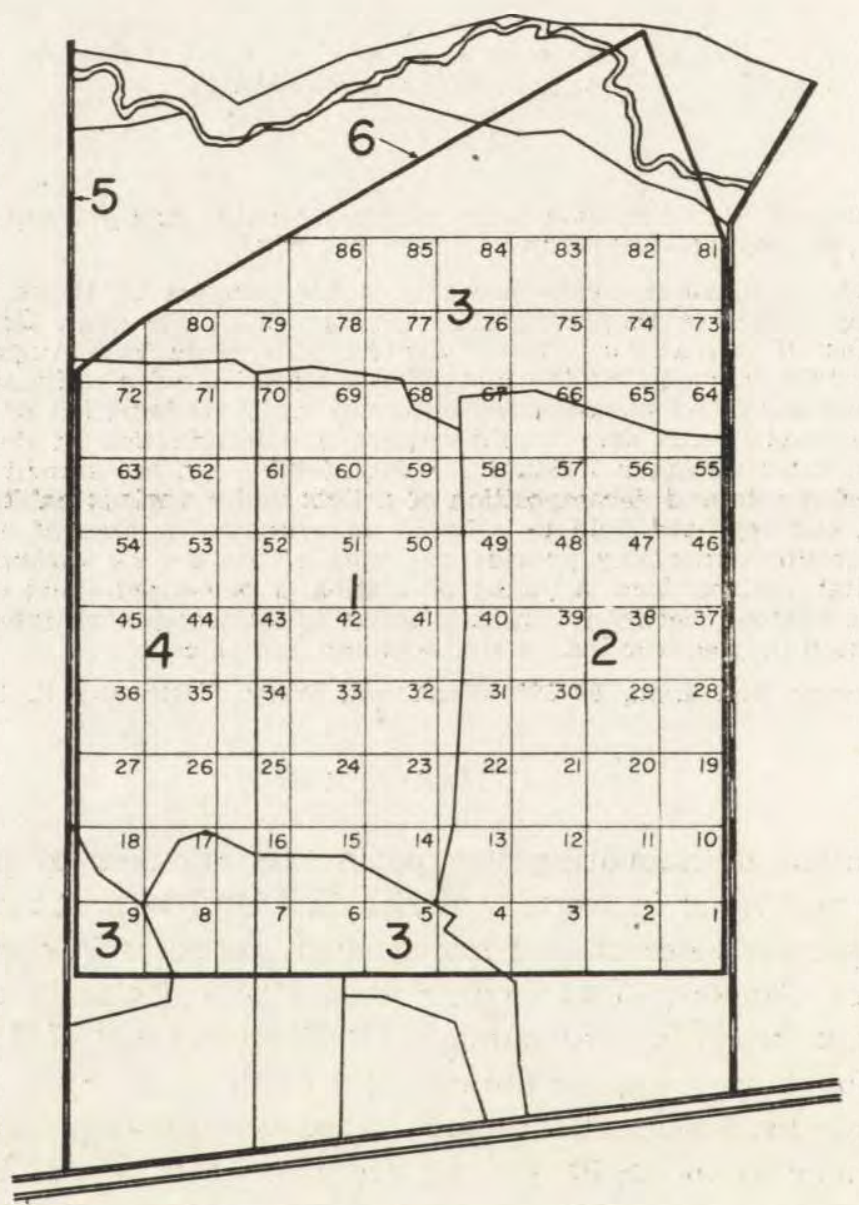

Fig. 1. Sketch of the enclosure in which roe deer pellet group counts were done. 1 - young plantation, 2-6 years old plantation, $27,500 \mathrm{~m}^{2} ; 2-$ pine thicket, $20-25$ years old, $52,500 \mathrm{~m}^{2} ; 3$ - pole-sized stand of pine, 50-55 years old, $42,805 \mathrm{~m}^{2}$; 4 - timber stand of pine, $120-125$ years old, $20,000 \mathrm{~m}^{2} ; 5-$ compartment lines; 6 - fence.

for roe deer since they are the most difficult of all ungulates to count (A nders on, 1953, 1961).

\section{MATERIAL AND METHODS}

Pellet-group counts were made in a $86,875 \mathrm{~m}^{2}$ enclosure (Fig. 1) at the Józefów forest district (Zamosć province). The enclosed area includes patches of the 
following forest associations: Dicrano-Pinetum typicum, Leucobryo-Pinetum molinietosum, Vaccinio uliginosi-Pinetum, and a riverside meadow.

The enclosure was divided into $8650 \times 50 \mathrm{~m}$ plots and four additional plots of irregular shape, but similar area. The plots were permanently marked with pegs and paint on bordering trees. Pellet-groups were counted and recorded monthly for each plot from August 1972 until May 1974. The counted pellet groups were dug into the soil to prevent double counting. The number of roe deer varied from two to six during the study.

The rate of pellet decomposition was observed on three series of summer samples and three series of winter samples of red deer droppings ${ }^{2}$. Each series, consisting of 10 groups of 20 pellets, was placed in the following habitats: pine thicket with alder admixture, young plantation, and timber stand with well developed understory. Fresh winter pellets were placed on plots April 16, 1973, and summer pellets July 13,1973. Thereafter, the number, colour, degree of dryness, and consistency of pellets were recorded monthly.

\section{RESULTS AND DISCUSSION}

\subsection{Number Estimates}

Pellet-group data (Table 1) were arranged according to seasons of year and subjected to an analysis of variance. Confidence interval $t \cdot S_{\tau}$ was determined by the so-called gap test (O $\mathrm{ktaba}, 1963)$, with the mean values arranged in a decreasing order.

The accumulation of pellets was significantly greater during spring than for any other season of the year (Table 2), probably because of the shift in roe deer diet to succulent young spring forage.

An estimate of animal numbers by the pellet-group count is possible only when the daily rate of defecation is known. Pa d a ig a (1970) found that a roe deer dismissed an average of 15.6 pellet-groups daily during winter. According to this value I succeeded in finding only $21 \%$ of the pellet-groups during the winter and $43 \%$ on an annual basis. The results are slightly better than those obtained by Downing et al. (1965), who estimated a deer population within $25 \%$ of its actual number by the pellet-group counts. My results revealed an enormous variation between and within seasons and show that I worked with a wide margin of error (Table 1).

According to $\mathrm{N}$ eff (1968) the following factors cause changes in the defecation rate: good environmental conditions and relatively high uptake of food, high water content in diet, rapid change in diet, high proportion of juvenile animals in population (young animals have a higher rate of defecation), and impact of captivity upon behaviour and psychics. In my study the habitat conditions and food uptake were rather constant throughout the study. There were no unnatural, rapid al-

2 The author realized the possibility of a differing rate of decomposition between red and roe deer pellets, but did not carry out tests with roe deer pellets. 
terations in the diet of enclosed roe deer and there were no fawns in the pen. The psychological effect of captivity should not operate here, because roe deer inhabited the pen for several years. Thus, it seems that

Table 1

Seasonal counts of roe deer pellet-groups.

\begin{tabular}{|c|c|c|c|c|c|c|}
\hline 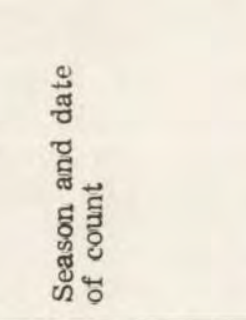 & 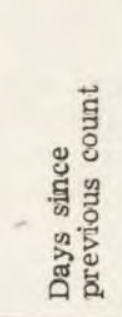 & 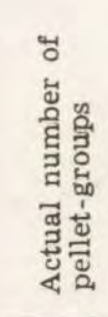 & 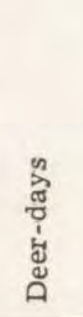 & 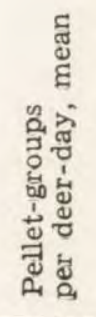 & 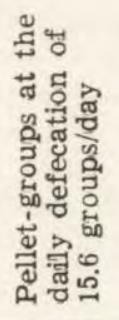 & 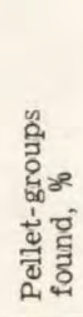 \\
\hline $\begin{array}{l}\text { Autumn } \\
24.09 .1972 \\
15.10 .1972 \\
20.11 .1972 \\
21.10 .1973\end{array}$ & $\begin{array}{l}27 \\
21 \\
36 \\
67\end{array}$ & $\begin{array}{r}594 \\
537 \\
1110 \\
435 \\
2676\end{array}$ & $\begin{array}{l}183 \\
105 \\
180 \\
201 \\
669\end{array}$ & $\begin{array}{l}3.2 \\
5.1 \\
6.2 \\
2.2 \\
4.0\end{array}$ & $\begin{array}{r}2,855 \\
1,638 \\
2,808 \\
3,136 \\
10,436\end{array}$ & $\begin{array}{l}20.8 \\
32.8 \\
39.5 \\
14.4 \\
25.6\end{array}$ \\
\hline $\begin{array}{l}\text { Winter } \\
28.01 .1973 \\
5.01 .1974\end{array}$ & $\begin{array}{l}68 \\
76\end{array}$ & $\begin{array}{r}478 \\
1389 \\
1867\end{array}$ & $\begin{array}{l}345 \\
228 \\
573\end{array}$ & $\begin{array}{l}1.4 \\
6.1 \\
3.3\end{array}$ & $\begin{array}{l}5,382 \\
3,557 \\
8,939\end{array}$ & $\begin{array}{r}8.9 \\
39.0 \\
20.9\end{array}$ \\
\hline $\begin{array}{l}\text { Spring } \\
18.03 .1973 \\
8.04 .1973 \\
24.04 .1973 \\
13.05 .1973 \\
27.05 .1973 \\
24.03 .1974 \\
21.04 .1974 \\
21.05 .1974\end{array}$ & $\begin{array}{l}49 \\
21 \\
15 \\
19 \\
14 \\
78 \\
28 \\
30\end{array}$ & $\begin{array}{r}1146 \\
2466 \\
1669 \\
596 \\
855 \\
1782 \\
1431 \\
514 \\
10,459\end{array}$ & $\begin{array}{r}245 \\
95 \\
60 \\
57 \\
42 \\
234 \\
84 \\
90 \\
907\end{array}$ & $\begin{array}{r}4.7 \\
26.0 \\
27.8 \\
10.5 \\
20.4 \\
7.6 \\
17.0 \\
5.7 \\
11.5\end{array}$ & $\begin{array}{r}3,822 \\
1,482 \\
936 \\
889 \\
655 \\
3,650 \\
1,310 \\
1,404 \\
14,149\end{array}$ & $\begin{array}{r}30.0 \\
166.4 \\
178.3 \\
67.0 \\
130.5 \\
48.8 \\
109.2 \\
36.6 \\
73.9\end{array}$ \\
\hline $\begin{array}{l}\text { Summer } \\
28.08 .1972 \\
11.06 .1973 \\
25.06 .1973 \\
10.07 .1973 \\
27.07 .1973 \\
15.08 .1973 \\
\text { Annual Mean }\end{array}$ & $\begin{array}{l}14 \\
14 \\
15 \\
17 \\
19\end{array}$ & \begin{tabular}{r|}
139 \\
318 \\
288 \\
422 \\
248 \\
91 \\
1,506 \\
16,508
\end{tabular} & $\begin{array}{r}89 \\
42 \\
42 \\
45 \\
51 \\
57 \\
326 \\
2475\end{array}$ & $\begin{array}{l}1.6 \\
7.6 \\
6.9 \\
9.4 \\
4.9 \\
1.6 \\
4.6 \\
6.7\end{array}$ & $\begin{array}{r}1,388 \\
655 \\
655 \\
702 \\
796 \\
889 \\
5,086 \\
38,610 \\
\end{array}$ & $\begin{array}{l}10.0 \\
48.5 \\
44.0 \\
60.1 \\
31.2 \\
10.2 \\
29.6 \\
42.8\end{array}$ \\
\hline
\end{tabular}

difficulties in locating pellets among herb layer vegetation and observers' error were responsible for the low percentage of groups located.

\subsection{Habitat Use}

The distribution of pellet-groups for 20 counts taken during 2 years is shown in Table 3 . This distribution significantly differs from Poisson's and negative binomial distributions. 
There was a statistically significant difference $(<0.05$ probability) in the density of pellet-groups (and indirectly in the extent of habitat use) between habitat types. The highest accumulation of roe deer pellets

Table 2

Seasonal differences between pellet-group means.

\begin{tabular}{lccccc}
\hline Statistics & Spring & \multicolumn{2}{c}{ Summer } & Autumn & Winter \\
\hline $\begin{array}{l}\text { mean } \\
t . S_{r}\end{array}$ & 14.93 & 5.33 & & 4.18 & 3.75 \\
& & $7.31^{*}$ & & $8.76^{-}$ & \multicolumn{2}{c}{$11.75^{-}$} & \\
\hline
\end{tabular}

* statistically significant, - statistically non-significant

Table 3

The distribution of roe deer pellet-group numbers in the pen.

\begin{tabular}{|c|c|c|c|}
\hline $\begin{array}{l}\text { Pellet-groups } \\
\text { on plot }\end{array}$ & Observations & $\begin{array}{l}\text { Pellet-groups } \\
\text { on plot }\end{array}$ & Observations \\
\hline 0 & 355 & 39 & 3 \\
\hline 1 & 200 & 40 & 2 \\
\hline 1 & 143 & 41 & 5 \\
\hline 3 & 147 & 42 & 7 \\
\hline 4 & 98 & 43 & 4 \\
\hline 5 & 73 & 44 & 2 \\
\hline 6 & 57 & 45 & 2 \\
\hline 7 & 69 & 46 & 2 \\
\hline 8 & 56 & 47 & 2 \\
\hline 9 & 48 & 48 & 1 \\
\hline 10 & 51 & 49 & 1 \\
\hline 11 & 30 & 50 & 0 \\
\hline 12 & 31 & 51 & 2 \\
\hline 13 & 27 & 52 & 5 \\
\hline 14 & 24 & 53 & 4 \\
\hline 15 & 15 & 54 & 0 \\
\hline 16 & 19 & 55 & 1 \\
\hline 17 & 14 & 56 & 1 \\
\hline 18 & 24 & 57 & 2 \\
\hline 19 & 9 & 58 & 0 \\
\hline 20 & 12 & 59 & 2 \\
\hline 21 & 12 & 60 & 0 \\
\hline 22 & 13 & 61 & 0 \\
\hline 23 & 12 & 62 & 2 \\
\hline 24 & 5 & 63 & 3 \\
\hline 25 & 8 & 64 & 1 \\
\hline 26 & 13 & 65 & 1 \\
\hline 27 & 9 & 66 & 0 \\
\hline 28 & 8 & 67 & 1 \\
\hline 29 & 6 & 68 & 3 \\
\hline 30 & 7 & 69 & 0 \\
\hline 31 & 15 & 70 & 0 \\
\hline 32 & 9 & 71 & 2 \\
\hline 33 & 1 & 72 & 1 \\
\hline 34 & 4 & 73 & 1 \\
\hline 35 & 4 & 74 & 0 \\
\hline 36 & 5 & 75 & 0 \\
\hline 37 & 5 & 76 & 17 \\
\hline 38 & 2 & & \\
\hline
\end{tabular}


( 0.119 group $\left./ \mathrm{m}^{2}\right)$ was found in the young plantation, the preferred feeding ground of roe deer. The density of pellet-groups was slightly less in the pole-size stand of pine $\left(0.099 \mathrm{group} / \mathrm{m}^{2}\right)$ and in the ecotone between various habitat types $\left(0.081\right.$ group $\left./ \mathrm{m}^{2}\right)$. The timber stand of pine $\left(0.039\right.$ group $\left./ \mathrm{m}^{2}\right)$ and the pine thicket $\left(0.025\right.$ group $\left./ \mathrm{m}^{2}\right)$ had the lowest accumulation of roe deer pellets (Fig. 1).

These results agree, in general, with those obtained for red deer (Dzięciolowski, 1974) where the sequence of habitat preference was timber stand, ecotone, and thicket.

\subsection{Rate of Pellet Decomposition}

The rate of decomposition and weathering of red deer pellets depended to some degree upon the place and time of their deposition. The most rapid decomposition and weathering occurred in the young plantation, and secondly in thickets. Pellets were maintained for the longest time under the timber stand canopy. Winter pellets decomposed and disintegrated in 3 months, whereas summer pellets disappeared in two months.

\section{CONCLUSIONS}

The pellet-group count is not a promising technique for estimating roe deer numbers in an unrestrained environment.

The adaptation of this technique to roe deer in our natural conditions would require an additional determination of daily defecation rates during individual seasons of year, determination of weathering rate and decomposition of pellets under various habitat conditions (W a $11 \mathrm{mo}$ et al. 1962), and repeated field tests based on a known number of animals.

Pellet-group counts may provide an index of use among various types of habitat by roe deer. My studies indicated that a young plantation, a pole-sized stand of pine, and ecotone zone between various habitat types were more intensively used by roe deer than a timber stand and a thicket.

Acknowledgement: Thanks are due to Dr. L. K. H alls (Nacogdoches, Texas) for critical review and numerous useful suggestions on the manuscript.

\section{REFERENCES}

1. Andersen J., 1953: Analysis of a Danish roe-deer population (Capreolus capreolus L.) based upon the extermination of the total stock. Danish Rev. Game Biol., 2: 127-155.

2. Andersen J., 1961: Biology and management of roe-deer in Denmark. La Terre et la Vie, 1: $41-53$.

3. Bennett L. J., English P. F. \& McCain R., 1940: A study of deer populations by use of pellet-group counts. J. Wildl. Manage., 4, 4: 398-403. 
4. Bowden D. C., Andersen A. E. \& Medin D. E. 1969: Frequency distributions of mule deer fecal group counts. J. Wildl. Manage., 33, 4: 895-905.

5. Daburon H., 1970: Methodes de recensement du cerf d'Europe (Cervus elaphus L.) en foret temperee melangee feuillus-resinoux en l'absence de neige. Trans. IX intern. Congr. Game Biol., Moscow: 289-293.

6. Downing R. L., Moore W. H. \& Kight J. 1965: Comparison of deer census techniques applied to a known population in a Georgia enclosure. Southeastern Game and Fish Commissioners Meeting, Tulsa, Oklahoma, October $11-13,1965$.

7. Dzięciołowski R. M., 1974: The use of pellet-group counts to census red deer (Cervus elaphus L.). New Zealand Wildlife, 44: 17-23.

8. Julander O., Fergus on R. B. \& Dealy J. E., 1963: Measure of animal range use by signs. Range Research Methods. A symposium. Denver, Colorado, May 1962. Misce. Publ. No 940, USDA, Forest Service: 102-108.

9. Kufeld R. C. 1968: Use of paint for marking deer pellet groups. J. Wildl. Manage., 32, 3: 592-596.

10. Neff D. J., 1968: The pellet-group count technique for big game trend, census, and distribution: a review. J. Wildl. Manage., 32, 3: 597-614.

11. Oktaba W., 1963: Elementy statystyki matematycznej i doświadczalnictwa rolniczego. Państw. Wyd. Nauk: $1-310$. Warszawa.

12. P a da ig a V., 1970. Opyt učeta čislennosti evropejskih kosul po zimnim defekacijam. Tr. Litov. Nauč.-issl. Inst. Les. Chozjajstva, 13: 265-266.

13. Robinette W. L., Fergus on R. B. \& G a shwiler J. S., 1958: Problems involved in the use of deer pellet group counts. North Amer. Wildlife Conf. Trans., 23: $411-425$.

14. Rogers G., Julander O. \& R obinet te W. L., 1958: Pellet group counts for deer census and range-use index. J. Wildl. Manage., 22, 2: 193-199.

15. Rye I L. A., 1972: Evaluation of pellet group surveys for estimating deer populations in Michigan. Michigan Depertament of Natural Resources. Research and Development Report No 250A.

16. Wa $11 \mathrm{moO}$. C., Jackson A. W., Hailey T. L. \& Carlis le R. L., 1962: Influence of rain on the count of deer pellet groups. J. Wildl. Manage, 26, 1: $50-55$.

17. Wel $\mathrm{ch}$ D., 1971: Evaluating the dung method of measuring animal numbers. Range Ecology Research. Ist Progress Report. Nature Conservancy. Natural Environment Research Council: 13-17.

18. Yurgenson P. B., 1970: Census of winter game numbers by the method of pellet group count. Trans. IX intern. Congr. Game Biologists. Moscow: 287-288.

Accepted, February 9, 1976.

Ryszard DZIĘCIOŁOWSKI

INWENTARYZACJA SARN METODA LICZENIA ODCHODÓW

Streszczenie

Badania miały na celu sprawdzenie czy metoda liczenia grup odchodów może być zastosowana do inwentaryzacji pogłowia sarn, Capreolus capreolus ( $\mathrm{L}$ in n a e u s, 
1753) oraz do określenia rozmiaru użytkowania różnych środowisk leśnych przez te zwierzęta.

Inwentaryzację odchodów prowadzono w zagrodzie o pow. 9 ha, zasiedlonej w okresie badań przez 2-6 sarn. Obszar zagrody podzielono na 86 dzialek o rozmiarach $50 \times 50 \mathrm{~m}$ i 4 działki o kształcie nieregularnym. Inwentaryzację grup odchodów sarnich prowadzono na całej powierzchni zagrody notując ich liczbę oddzielnie dla poszczególnych działek. W okresie od sierpnia 1972 r. do maja 1974 r. przeprowadzono 20 inwentaryzacji (Tabela 1).

Wykazano, że nagromadzenie odchodów sarnich wykazuje statystycznie istotne zróżnicowanie $w$ zależności od pory roku (Tabela 2). Jedynie wiosną nagromadzenie odchodów różni się $\mathrm{w}$ sposób istotny od odpowiadających mu wartości $\mathrm{w}$ innych porach roku. W obliczeniach przyjęto za P adaig ą (1970), że sarna wydala przeciętnie 15,6 grup odchodów na dobę. Znajdowano tylko $21 \%$ grup odchodów podczas inwentaryzacji zimowych, $74 \%$ latem i $43 \%$ - w skali całorocznej (Tabela 1).

Rozkład wyników inwentaryzacji odchodów (Tabela 3) różni się od rozkładów Poissona i ujemnego dwumianu. Rozmieszczenie grup odchodów sarn (a zatem frekwencja zwierząt) $w$ różnych środowiskach w obrębie zagrody (Ryc. 1) wskazuje, że uprawa leśna, drągowina sosnowa i strefa ekotonu są bardziej preferowane przez sarny, niż starodrzew i młodnik.

Tempo rozkładu i rozmywania odchodów przez deszcz zaleźy w pewnym stopniu od miejsca ich złożenia, najszybsze jest na uprawie, pośrednie - w młodniku a najwolniejsze - pod okapem starodrzewia. Odchody zimowe rozkładały się i rozsypywały w ciągu 3 miesięcy a odchody letnie w ciągu dwóch miesięcy.

Metoda liczenia grup odchodów nie jest zatem obiecującą techniką szacowania liczebności sarn $w$ środowisku otwartym. Dostosowanie tej metody do sarn i naszych warunków przyrodniczych wymaga okreslenia dobowego tempa wydalania odchodów w poszczególnych porach roku, określenia tempa wietrzenia i rozkłađu odchodów w różnych warunkach środowiskowych oraz powtarzanych prób terenowych w oparciu o znaną liczbę zwierząt. Metoda liczenia grup odchodów może być natomiast stosowana jako wskaźnik intensywności użytkowania przez sarny różnych typów środowiska. 